\title{
KONSEPTUALISASI DESTINASI WISATA PINTAR
}

\author{
Raden Willy Ananta Permadi, M. Sapari Dwi Hadian, Cipta Edyana, Heriyadi Rakhmat \\ Sekolah Pascasarjana Universitas Padjadjaran, Prodi Pariwisata Berkelanjutan \\ Jl. Dipati Ukur No.35, Lebakgede, Kecamatan Coblong, Kota Bandung, Jawa Barat 40132 \\ E-mail:radenwilly@gmail.com
}

\begin{abstract}
ABSTRAK
Istilah pintar mewakili kata pemasaran untuk semua hal yang ada tertanam atau ditingkatkan oleh teknologi. Satu konsep cerdas, yang telah didapat momentum dalam beberapa tahun terakhir, adalah Smart City. Ini terutama berfokus pada cara meningkatkan kualitas hidup warga dengan menggunakan Teknologi Informasi dan Komunikasi gies (ICT). Makalah ini bertujuan untuk mengeksplorasi dimensi mana kecuali teknologi kritis untuk pengembangan Smart City dan Destinasi wisata Cerdas. Mengikuti beberapa pendekatan studi kasus, makalah ini mengembangkan kerangka kerja untuk kecerdasan di kota-kota dan destinasi wisata. Penelitian eksplorasi ini berpendapat bahwa kepemimpinan, inovasi, dan modal sosial yang didukung oleh modal manusia adalah konstruksi fundamental kecerdasan. Aplikasi teknologi dan TIK enabler, yang mendukung konstruksi inti tujuan cerdas. Hasil yang diperoleh adalah untuk membahas bagaimana mengubah 'kecerdasan' ke pariwisata dan level yang lebih tinggi.
\end{abstract}

Kata kunci; Smart City, TIK, Destinasi Wisata Pintar, Teknologi

\section{CONCEPTUALIZATION OF SMART TOURISM DESTINATION}

\begin{abstract}
The term smart represents the word marketing for everything that is embedded or enhanced by technology. One smart concept, which has gained momentum in recent years, is Smart City. It mainly focuses on ways to improve the quality of life of citizens by using Information and Communication Technology (ICT). This paper aims to explore which dimensions except technology are critical for the development of Smart City and Smart Travel Destinations. Following a number of case study approaches, this paper develops a framework for intelligence in cities and tourist destinations. This exploratory research argues that leadership, innovation, and social capital supported by human capital are fundamental constructs of intelligence. Application of technology and ICT enablers, which support the construction of smart core goals. The results obtained are to discuss how to change 'intelligence' to tourism and higher levels.
\end{abstract}

Key words; Smart City, ICT, Smart Tourism Destinations, Technology

\section{PENDAHULUAN}

Selama beberapa dekade terakhir perkembangan Teknologi Informasi dan Komunikasi (TIK) memperkenalkan teknologi baru seperti Internet, Sosial Media, NFC, Augmented Reality, Komputasi Ubiquitous, dan Mesin ke Mesin. Baru-baru ini, teknologi seperti Cloud Computing, Internet dari Hal-hal, dan penerapannya pada masalah logistik yang rumit di dalam kota, memicu a Konsep 'baru', di sektor publik, swasta dan akademik sama. Smart City sebagai konsep yang secara strategis memperkenalkan TIK di perkotaan daerah untuk memasukkan proses perkotaan dalam kontemplasi meningkatkan kepekaan kota sekaligus meningkatkan kualitas hidup warganya. Konsep ini terutama didapat popularitas dalam bidang kebijakan dan semakin banyak literatur yang berkembang telah diterbitkan. Sastra pertama dan terutama, membahas pentingnya implementasi TIK untuk keberhasilan pengembangan Smart City. Meski begitu, topik-topik seperti inovasi, modal intelektual dan mendesain ulang operasi internal juga penting. Baru-baru ini, gagasan Destinasi Wisata Cerdas muncul, berkembang dari konsep Smart City. Sampai saat ini ada sedikit penelitian yang dilakukan di bidang Destinasi Wisata
Cerdas, di mana para peneliti pada dasarnya focus tentang pentingnya TIK di destinasi. Ini penelitian menganalisis konstruksi mendasar dari Smart City dan bertujuan untuk menyediakan kerangka kerja holistik untuk Destinasi Wisata Cerdas untuk memanfaatkan penuh TIK infrastruktur dan aplikasi teknologi untuk memasok kreasi bersama nilai dan pengalaman untuk pelancong dan daya saing dan margin keuntungan untuk tujuan.

Saat ini, gerakan global pemerintah berkembang, dan publik dan swasta agensi menggabungkan konsep 'kecerdasan' dalam kontemplasi perkembangan kebijakan dan strategi baru untuk menargetkan pembangunan berkelanjutan dan pertumbuhan ekonomi (Pusat Pemerintahan 2003). Dengan semakin populernya Smart City, para sarjana telah mencoba mendefinisikan konsep ini. Saat ini, beberapa deskripsi adalah tersedia, yang digunakan dalam berbagai keadaan di seluruh dunia dan tidak ada definisi satu ukuran untuk semua (Nam dan Pardo 2011)). Istilah 'pintar' tampaknya telah menjadi frase menangkap untuk teknologi yang tertanam dalam layanan dan produk (Pusat Tata Kelola 2003) dan seringkali TIK diposisikan pada actual inti dari konsep Smart City (Nam dan Pardo 2011; Su et al. 2011). Tetap saja, TIK 
telah lama dikaitkan dengan pertumbuhan ekonomi dan sejak perkembangan komputer orang telah menyatakan pentingnya teknologi untuk ekonomi (Avgerou 2003; Porter dan Millar 1985). Oleh karena itu, Caragliu et al. (2011) berpendapat bahwa TIK bukan satu-satunya faktor keberhasilan untuk Smart City dan masalah seperti inovasi, kreativitas, modal manusia, dan makhluk mampu menandakan daya tarik produk dan layanan seyogyanya kesetaraan termasuk (Centre on Governance 2003). Nam dan Pardo (2011) menekankan pentingnya tenaga kerja pengetahuan, ruang kolaboratif, inovasi, dan sosial modal. Juga Lombardi et al. (2012) menekankan pentingnya manusia dan sosial modal, inovasi, dan hubungan dan inter-koneksi yang dapat didukung melalui model triple-helix. Dalam topik Smart City ini, Cohen (2011) dikonsep Smart Wheel Kota, yang mendefinisikan enam dimensi kecerdasan penting untuk pengembangan Smart City termasuk (1) Pemerintahan Cerdas, (2) Lingkungan Cerdas, (3) Mobilitas Cerdas, (4) Ekonomi Cerdas, (5) Orang Cerdas, dan (6) Hidup Cerdas. Namun, dimensi ini hanya dapat dilihat sebagai hasil saat konstruksi mendasar dari Smart City sudah ada. Konstruk yang mendasari. Oleh karena itu Roda Smart City dibangun di atas teori daya saing regional, modal sosial dan manusia, TIK, infrastruktur, dan ekonomi (Lombardi et al. 2012). Akibatnya, Caragliu et al. (2011, p.70) mengklaim bahwa kota bias didefinisikan sebagai pintar "ketika investasi dalam modal manusia dan sosial dan tradisional (transportasi) dan infrastruktur komunikasi modern (TIK) memicu eko berkelanjutan pertumbuhan nomik dan kualitas hidup yang tinggi, dengan pengelolaan alam yang bijaksana sumber daya, melalui pemerintahan partisipatif". Secara keseluruhan, Smart City dapat diterima sebagai "keseluruhan organik" dan sebagai sistem yang terhubung di mana orang, pengunjung dan warga sama, adalah aspek yang paling penting (Kanter dan Litow 2009). Meski begitu, konsep Smart City tidak berdiri sendiri dan mencakup beragam industri, termasuk industri pariwisata (Guo et al. 2014). Meski utama Tujuan dari Smart City adalah untuk meningkatkan kualitas hidup warganya, penelitian ini menunjukkan perlunya fokus pada pariwisata karena, dalam sebagian besar kasus, itu adalah sumber pendapatan untuk banyak kota di Eropa (Taaffe 2014).

Destinasi wisata dikenal sebagai campuran produk dan layanan wisata (Buhalis 2000) dan mereka dianggap sebagai sistem kompleks yang sulit kelola (Fyall 2011). Saling ketergantungan dari berbagai pemangku kepentingan dan industri mempersulit manajemen sementara pada saat yang sama menyebabkan fragmen dalam kontrol dan pengembangan destinasi wisata. Selain nilai dan budaya yang berbeda, dan dampak yang saling terkait pada populasi lokal semua membuat sistem perencanaan yang kompleks dalam destinasi wisata (Jamal dan Jamrozy 2006). Awalnya, destinasi wisata disusun dengan persediaan dan sisi permintaan di mana keberhasilan tujuan diprakarsai oleh pengembangan sumber daya kritis yang dikenal sebagai enam A (atraksi, aksesibilitas, fasilitas, paket yang tersedia, kegiatan, layanan tambahan). Ini digabung dalam kontemplasi untuk menambah nilai pengalaman wisata sekaligus meningkatkan laba dan manfaat untuk tujuan (Buhalis 2000). Untuk memastikan keberhasilan destinasi wisata Ritchie dan Crouch (2005) stress pentingnya sumber daya manusia dan inovasi dalam kombinasi dengan kerja sama dan kolaborasi di tingkat lokal dan regional. Serupa, seakan pentingnya inovasi sambil memasukkan komunitas lokal di dalamnya proses inovasi. Lingkungan dengan hubungan berkualitas tinggi adalah yang terbaik penting untuk pengembangan pengetahuan dan oleh karena itu pengusaha pariwisata harus menyelaraskan tujuan mereka untuk meningkatkan pengalaman pariwisata (Murphy 1997). Kerja sama itu penting, masih kepemimpinan yang dilakukan secara kolektif dan jaringan cara sangat penting (Zehrer et al. 2014). Selama dua dekade terakhir, lebih banyak informasi telah tersedia dalam integrasi interdisipliner, inovasi struktural, keanggotaan, dan kolaborasi untuk berhasil mengelola tujuan (Jamal dan Jamrozy 2006). Namun, perhatian yang lebih besar diperlukan untuk implementasi mereka dalam pariwisata tujuan (Jamal dan Jamrozy 2006). Cohen (2011) berpendapat bahwa terutama konsep yang disebutkan sebelumnya dianggap sebagai landasan kecerdasan, yang diaktifkan dan didukung melalui integrasi TIK di seluruh Smart City. Sampai sekarang literatur tentang Destinasi Wisata Cerdas berpendapat demikian tujuan pariwisata menggabungkan TIK dalam pengembangan dan produksi proses pariwisata (Wang et al. 2013). Konsekuensinya, Destinasi wisata Cerdas dapat dirasakan sebagai tempat memanfaatkan alat teknologi yang tersedia dan teknik untuk memungkinkan permintaan dan penawaran untuk bersama-sama menciptakan nilai, kesenangan, dan pengalaman untuk pariwisata dan kekayaan, keuntungan, dan manfaat bagi organisasi dan tujuan. Meski begitu, penelitian dilakukan pada kecerdasan destinasi wisata terutama berfokus pada implementasi teknologi (Guo et al. 2014; Wang et al. 2013; Zhu et al. 2014). Hanya kertas teoretis Buhalis dan Amaranggana (2014) telah menyentuh gagasan membangun Smart Tourism Destinations sebagai kerangka kerja generik dari konsep-konsep turunan yang menggabungkan, keberlanjutan, dan inklusif didasarkan pada konsep Smart City. Karenanya, makalah ini membahas konsep 'kecerdasan' dan bertujuan untuk menyediakan kerangka kerja holistic untuk Destinasi Wisata Cerdas.

\section{METODE}

Untuk mengeksplorasi faktor-faktor yang mempengaruhi kecerdasan Pariwisata Cerdas tujuan, makalah ini telah disusun dengan sifat penelitian eksplorasi berdasarkan studi kasus. Studi kasus di sini digunakan untuk mengidentifikasi faktor-faktor mana berkontribusi pada pengembangan Smart City dan Smart Tourism Destination. Metodologi studi kasus sering diterapkan 
ketika penelitian masih awal, tahap formatif (Benbasat et al. 1987). Bidang penelitian Smart City adalah multidisiplin sekali dan meskipun para sarjana telah fokus pada topik ini, ini lapangan masih agak muda. Selain itu, bidang penelitian ini biasanya ditandai oleh perubahan konstan dalam inovasi dan teknologi. Oleh karena itu, studi kasus metodologi memungkinkan untuk mendapatkan pengetahuan, dan untuk mengeksplorasi bagaimana ketiganya terbentuk Smart City mengembangkan kecerdasan mereka. Studi ini melakukan studi kasus berganda penelitian karena memungkinkan untuk analisis lintas kasus dan tinjauan umum yang lebih luas hasil penelitian (Bonoma 1985). Sampai saat ini, ada berbagai peringkat yang tersedia untuk Smart City. Makalah ini menggunakan pertama studi "Parlemen Smart City di Uni Eropa", yang melakukan analisis mendalam tentang kota EU28 dengan setidaknya 100.000 penduduk tentang inisiatif Smart City mereka. Smart City yang dipilih termasuk Barcelona, Amsterdam, dan Helsinki. Khususnya, kota-kota itu telah dipilih sebagai kota menghasilkan solusi Smart City paling inovatif (Parlemen Eropa 2014)). Selain itu, pemilihan sampel didasarkan pada peringkat yang dikembangkan oleh Boyd Cohen (2014). Sindikat ini memiliki variasi peringkat global dan regional yang tinggi Komponen Smart City dan, juga di peringkat ini, Barcelona, Amsterdam, dan Helsinki terletak di 10 Smart City teratas di Eropa.

\section{HASIL DAN PEMBAHASAN}

Hasil dan pembahasan berisi hasil-hasil temuan penelitian dan pembahasannya secara ilmiah. Tuliskan temuan-temuan ilmiah (scientific finding) yang diperoleh dari hasil-hasil penelitian yang telah dilakukan tetapi harus ditunjang oleh data-data yang memadai. Temuan ilmiah yang dimaksud di sini adalah bukan data-data hasil penelitian yang diperoleh. Temuan-temuan ilmiah tersebut harus dijelaskan secara saintifik meliputi: Apakah temuan ilmiah yang diperoleh? Mengapa hal itu bisa terjadi? Mengapa trend variabel seperti itu? Semua pertanyaan tersebut harus dijelaskan secara ilmiah, tidak hanya deskriptif, dan ditunjang oleh data empiris yang memadai. Selain itu, harus dijelaskan juga perban-dingannya dengan hasil-hasil para peneliti lain yang hampir sama topiknya. Hasil-hasil penelitian dan temuan harus bisa menjawab hipotesis dan/atau pertanyaan penelitian di bagian pendahuluan.

Tabel (maksimal 6 tabel) dan Gambar (maksimal 6 gambar) diletakkan di dalam kelompok teks sesudah tabel atau gambar tersebut dirujuk. Setiap gambar harus diberi judul gambar di sebelah bawah gambar tersebut dan bernomor urut angka diikuti dengan judul gambar. Setiap tabel harus diberi judul tabel dan bernomor urut angka di sebelah atas tabel tersebut diikuti dengan sumber tabel.

Gambar-gambar harus dijamin dapat tercetak dengan jelas (ukuran font, resolusi dan ukuran garis harus yakin tercetak jelas berupa jpeg). kelopok Gambar terdiri dari diagram/skema, tabel dan sebaiknya diletak-kan sesuai kolom diantara kelompok teks atau jika terlalu besar diletakkan di bagian tengah halaman. Tabel tidak boleh mengandung garis-garis vertikal, sedangkan garis- garis horisontal diperbolehkan tetapi hanya yang pentingpenting saja.

\section{Tabel 1. Korelasi Antar Variabel}

\begin{tabular}{lcc}
\hline \multirow{2}{*}{ Aspek Dukungan Keluarga } & \multicolumn{2}{c}{ Stres Kerja } \\
\cline { 2 - 3 } & \multicolumn{1}{c}{$r$} & $p$ \\
\hline Dukungan emosional & 0,167 & $\ldots \ldots \ldots \ldots$ \\
Dukungan penghargaan & 0,255 & $\ldots \ldots \ldots \ldots$ \\
Dukungan nasihat & 0,285 & $\ldots \ldots \ldots \ldots \ldots$ \\
Dukungan instrument & $\ldots \ldots \ldots \ldots$ & $\ldots \ldots \ldots \ldots \ldots$ \\
\hline
\end{tabular}

Keterangan: Tuliskan nilai $p$ (bukan $p<0,05$ atau $p<0,001$ ) kecuali jika hasil analisisnya menunjukkan $\mathrm{p}=$ 0,000 maka harus dituliskan $\mathrm{p}<0,001$; atau jika hasilnya $\mathrm{p}=1,000$ maka harus dituliskan $\mathrm{p}>$ 0,99 . Untuk memudahkan mengenali signifikansi, bisa ditambahkan tanda $* *$ untuk nilai $\mathrm{p}<0,001$ dan * untuk nilai $\mathrm{p}<0,05$.

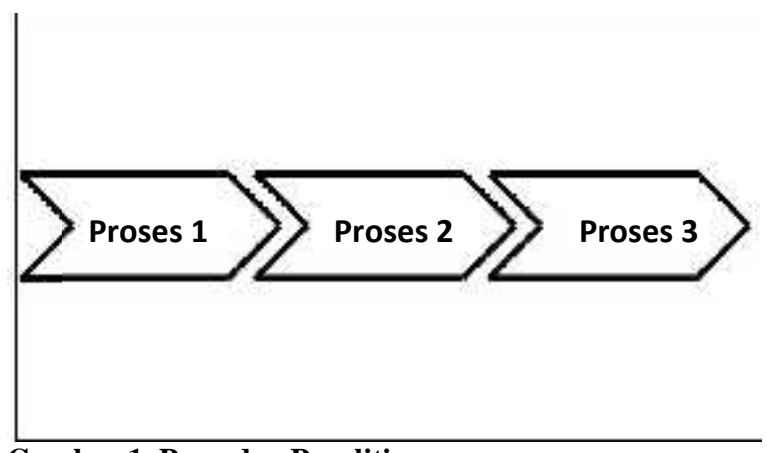

Gambar 1. Prosedur Penelitian

\section{SIMPULAN}

Bagian Simpulan terdiri dari satu paragraf saja namun menggambarkan jawaban dari hipotesis dan/atau tujuan penelitian atau temuan ilmiah yang diperoleh. Simpulan bukan berisi perulangan dari hasil dan pembahasan, tetapi lebih kepada ringkasan hasil temuan seperti yang diharapkan di tujuan penelitian. Bila perlu, di bagian akhir simpulan dapat juga dituliskan hal-hal yang akan dilakukan terkait dengan gagasan selanjutnya dari penelitian tersebut.

\section{UCAPAN TERIMA KASIH (bila ada)}

Ucapan terima kasih terutama ditujukan kepada pemberi dana penelitian atau donatur dan pihak-pihak yang membantu pelaksanaan penelitian yang kontribusinya tidak cukup signifikan untuk dimasukkan dalam kelompok penulis (authorship).

\section{DAFTAR PUSTAKA}

Avgerou, C. (2003). Hubungan antara TIK dan pertumbuhan ekonomi dalam wacana pembangunan. Dalam M. Korpela, R. Montealegre, \& A. 
Poulymenakou (Eds.), Informasi organisasi sistem dalam konteks globalisasi (hlm. 373-386). Berlin: Springer.

Bakici, T., Almirall, E., \& Wareham, J. (2012). Inisiatif Smart City: Kasus Barcelona. Jurnal Ekonomi Pengetahuan, 4, 135-148.

Benbasat, I., Goldstein, D., \& Mead, M. (1987). Strategi penelitian kasus dalam studi informasi sistem. MIS Quarterly, 11 (3), 369-386.

Berry, CR, \& Glaeser, EL (2005). Perbedaan tingkat sumber daya manusia di seluruh kota. Dokumen dalam Ilmu Regional, 84 (3), 407-444.

Bonoma, T. (1985). Penelitian kasus dalam pemasaran: Peluang, masalah, dan proses. Jurnal Riset Pemasaran, 22 (2), 199-208.

Buhalis, D. (2000). Pemasaran tujuan kompetitif di masa depan. Manajemen pariwisata, 21, 97-116.

Caragliu, A., Del Bo, C., \& Nijkamp, P. (2011). Smart City di Eropa. Jurnal Urban Teknologi, 18 (2), 65-82.

Cocchia, A. (2014). Smart City dan digital: Tinjauan literatur yang sistematis. Dalam RP Dameri \&

Dameri, RP (2014). Membandingkan Smart City dan digital: Inisiatif dan strategi di Amsterdam dan Genoa. Apakah digital dan / atau pintar? Dalam RP Dameri \& C. Rosenthal-Sabroux (Eds.), Smart City (hlm. 45-88). Berlin: Springer.

Fyall, A. (2011). Manajemen destinasi: Tantangan dan peluang. Di Y. Wang \& A. Pizam (Eds.), Pemasaran dan manajemen tujuan: Teori dan implikasi (hal. 340-358). Patrick: Cabi.

Guo, Y., Liu, H., \& Chai, Y. (2014). Menanamkan konvergensi Smart City dan pariwisata internet barang di Cina: Perspektif muka. Kemajuan dalam Perhotelan dan Pariwisata Penelitian, 2 (1), 54-69.

Hielkema, H., \& Hongisto, P. (2012). Tidak mengembangkan Smart City Helsinki: Peran kompetisi untuk aplikasi data terbuka. Jurnal Ekonomi Pengetahuan, 4, 190-204.

Jamal, T., \& Jamrozy, U. (2006). Jaringan dan kemitraan kolaboratif untuk tujuan terpadu manajemen tion. Di D. Buhalis \& C. Costa (Eds.), Dinamika pengelolaan pariwisata: Tren, manajemen, dan peralatan (hlm. 164-172). Amsterdam: Elsevier.

Kitchin, R. (2013). Kota waktu nyata? Data besar dan urbanisme yang cerdas. GeoJournal, 79 (1), 1-14. Kogan, N. (2014). Penelitian eksplorasi tentang faktor-faktor keberhasilan dan tantangan proyek Smart City penelitian eksplorasi tentang faktor-faktor keberhasilan dan tantangan proyek Smart City, Kyung Hee Universitas.

Lombardi, P., Giordano, S., Farouh, H., \& Yousef, W. (2012). Memodelkan kinerja Smart City Inovasi: The European Journal of Social Science Research, 25 (2), 137-149.

Murphy, PE (1997). Manajemen kualitas dalam pariwisata perkotaan. Chichester: Wiley.

Nam, T., \& Pardo, TA (2011). Mengkonsep Smart City dengan dimensi teknologi, orang, dan institusi. Dalam Prosiding pemerintah digital internasional 12 tahunan konferensi penelitian tentang inovasi pemerintah digital di masa-masa yang penuh tantangan - dg.o'11 (hlm. 282-291). New York, NY: ACM.

Pirnar, I., Bulut, C., \& Eris, ED (2012). Meningkatkan kinerja dan daya saing perusahaan pariwisata melalui inovasi: Tren dan aplikasi. Dalam Pencerahan pariwisata: kompetisi konferensi internasional pertama dan inovasi dalam pariwisata: tantangan baru dalam lingkungan yang tidak pasti (hlm. 133142). Serbet.

Prats, L., Guia, J., \& Molina, F.-X. (2008). Bagaimana destinasi wisata berkembang: Gagasan tentang Sistem Inovasi Lokal Pariwisata. Penelitian Pariwisata dan Perhotelan, 8 (3), 178-191.

Ritchie, JR, \& Crouch, GI (2005). Model daya saing tujuan. Kompetitif tujuan: Perspektif pariwisata berkelanjutan (hal. 60-78). Patrick: Cabi.

Su, K., Li, J., \& Fu, H. (2011). Smart City dan aplikasinya. Pada konferensi internasional 2011 tentang elektronik, komunikasi dan kontrol (ICECC) (hlm. 1028-1031).

Zehrer, A., Raich, F., Siller, H., \& Tschiderer, F. (2014). Jaringan kepemimpinan di tujuan. Dalam D. Harald Pechlaner, \& Dr. M. Metin Kozak (Eds.), Tourism Review, 69 (1), 59-73.

Zhu, W., Zhang, L., \& Li, N. (2014). Tantangan, perubahan fungsi pemerintah dan perusahaan dalam pariwisata cerdas Cina. Dalam Z. Xiang \& L. Tussyadiah (Eds.), Informasi dan Komunikasi Teknologi di Pariwisata 2014. Dublin: Springer. 